\title{
STUDI PROSES KOAGULASI AIR BAKU UNTUK AIR BERSIH DI WILAYAH BENCANA PASCA TSUNAMI KABUPATEN ACEH BESAR
}

\author{
Ignasius D.A. Sutapa \\ Pusat Penelitian Limnologi - LIPI \\ Kompleks LIPI - Cibinong, Jalan Prof. Doddy Tisna Amidjaya, \\ PO BOX 454, Cibinong, Bogor \\ Email : ignasiussutapa@chenmt.com / ignasdas@yahoo.co.id
}

\begin{abstract}
Abstrak
Proses koagulasi flokulasi dalam pengolahan air minum sangat penting untuk ditinjau lebih jauh karena mempunyai pengaruh yang sangat besar terhadap proses purifikasi air berikutnya dan kualitas air produksi. Jenis koagulan yang sering dipakai adalah alumunium sulfat (alum) dan poly alumunium chloride (PAC). Tujuan penelitian ini adalah untuk menentukan tipe dan konsentrasi optimal koagulan yang diaplikasikan pada air baku berupa air permukaan di wilayah bencana pasca tsunami. Hal ini sangat diperlukan untuk membuat perencanaan rancangan instalasi pengolahan air bersih di wilayah tersebut. Jar test koagulan dilakukan untuk menentukan efisiensi koagulasi dan waktu sampling. Dari hasil penelitian ini dapat disimpulkan kekeruhan air baku mempengaruhi waktu sedimentasi. Pada kekeruhan di bawah 15 Nephelometric Turbidity Unit (NTU), waktu optimum sedimentasi adalah lima menit, tetapi pada air baku yang kekeruhannya di atas 15 NTU, waktu sedimentasi lebih cepat yaitu satu menit saja. Dari hasil jar tes yang dilakukan terhadap air di sungai Krueng Raya dapat dilihat bahwa air sungai Krueng Raya dapat diolah dengan bahan koagulan aluminium sulfat pada dosis 20 ppm, sedangkan jika menggunakan bahan koagulan PAC memerlukan dosis optimal 15 ppm.
\end{abstract}

Kata kunci : koagulan, efisiensi, koagulasi, kualitas air

\begin{abstract}
The coagulation - flocculation process in potable water treatment is very important to be studied in greater detail, since it has a very major impact on subsequent water purification processes and the quality of the water product. Types of coagulant that are commonly used are aluminum sulfate (alum) and poly-aluminum chloride (PAC). The objective of this research was to determine the optimum coagulant type and concentration to be applied for the treatment of surface water in post-tsunami disaster areas. This research is urgently required to design clean water installation in such area. Jar test of coagulants was performed to measure the efficiency of coagulation and sampling interval. From the obtained results, it can be concluded that the raw water turbidity influences the sedimentation time. At turbidity below $15 \mathrm{NTU}$, the optimum sedimentation time was 5 minutes. At turbidities above $15 \mathrm{NTU}$, the sedimentation was quicker, namely 1 minute. Based on jar test results on Krueng Raya river water, it can be observed that this river water can be treated with aluminum sulfate coagulant at $20 \mathrm{ppm}$ dose. When PAC coagulant was used, the optimum dose was $15 \mathrm{ppm}$.
\end{abstract}

Keyword: coagulant, efficiency, coagulation, water quality. 


\section{Pendahuluan}

Air bersih merupakan faktor yang keberadaannya tak dapat ditawar lagi untuk menunjang keberlangsungan hidup manusia khususnya maupun makhluk hidup lainnya. Air bersih harus tersedia setiap saat. Berkaitan dengan tercemarnya sumber-sumber air bersih dan rusaknya berbagai instalasi dan jaringan air bersih karena bencana tsunami, maka rehabilitasi dan konstruksi dalam hal penyediaan air bersih adalah hal yang mutlak untuk dilakukan.

Air permukaan di daerah pasca bencana di kota atau kabupaten di Provinsi Nangroe Aceh Darussalam, pada umumnya memiliki karakteristik berwarna coklat sampai kehitaman, keruh, dan berbau. Air baku tersebut pada dasarnya tidak memenuhi syarat untuk dijadikan air baku air minum Dibandingkan dengan air permukaan lainnya yang bersifat tawar, maka air di daerah pasca bencana tsunami perlu diolah secara spesifik dengan menambah tahapan dalam proses pengolahannya.

Pengolahan air minum dimaksudkan untuk mengurangi jumlah mikroorganisme patogen, memperbaiki turbiditas, rasa dan bau, membuang mineral dan materi organik serta inorganik berbahaya lainnya yang terlarut dalam air. Proses utama pengolahan air bersih meliputi penapisan, koagulasi, flokulasi, sedimentasi, dan filtrasi. Pada umumnya, air permukaan mengandung berbagai macam partikel koloid yang mempengaruhi turbiditas dan warna air. Sejumlah besar partikel yang tersuspensi dalam air berukuran sangat kecil sehingga tidak dapat dihilangkan melalui proses sedimentasi atau filtrasi Sifat stabil partikel ini dikarenakan partikel tersebut bermuatan negatif. Proses destabilisasi partikel ini diperoleh melalui proses pengadukan dengan penambahan koagulan. Proses ini disebut koagulasi (McGhee, 1991). Proses flokulasi merupakan proses fisik yang mendorong partikel-partikel hasil penetralan muatan membentuk agregasi partikel berukuran besar sehingga lebih mudah mengendap.

Koagulan merupakan reagen kimia yang dapat mendorong terjadinya destabilisasi partikel berukuran koloid dalam proses koagulasi. Koagulan berbasis aluminium seperti alum $\left(\mathrm{Al}_{2}\left(\mathrm{SO}_{4}\right)_{3} \cdot \mathrm{H}_{2} \mathrm{O}\right)$ atau Poly-Aluminium Chiloride (PAC) merupakan jenis koagulan yang umum digunakan pada pengolahan air minum untuk meningkatkan penurunan materi partikel, koloid dan substansi terlarut lainnya melalui proses koagulasi (Gebbie, 2001).

Keterbatasan kinerja alum ini membuat jenis koagulan lain mulai banyak dipergunakan, yaitu Poly-Aluminium Chloride (PAC) sebagai alternatif alum. PAC mempunyai kisaran $\mathrm{pH}$ optimum yang lebih luas dibanding dengan alum yaitu 5,0-8,5 (American Society of Civil Engineering and American Water Works Association, 1996). Keuntungan lain yang didapatkan dengan menggunakan PAC telah dibuktikan dalam penelitian Singh dkk. (2005) yaitu bahwa turbiditas air hasil koagulasi dengan PAC lebih rendah dibandingkan alum pada penggunaan konsentrasi yang sama.

Penelitian ini bertujuan untuk menentukan tipe dan konsentrasi optimal koagulan, yang diaplikasikan pada air baku berupa air permukaan di wilayah bencana pasca tsunami. Hal ini sangat diperlukan untuk membuat perencanaan rancangan instalasi pengolahan air bersih di wilayah tersebut.

\section{Metodologi}

Beberapa parameter utama yang mempengaruhi kualitas air baku (pada air daerah pasca bencana) dalam sistem pengolahan air bersih adalah warna, tingkat kekeruhan, kandungan bahan organik dan tingkat keasaman. Untuk itu perlu dikaji jenis air baku yang akan diolah khususnya untuk daerah pasca bencana

Flokulasi adalah proses lanjutan dan koagulasi. Terbentuknya flok-flok yang baik biasanya diawali oleh proses koagulasi yang efisien. Kualitas flok-flok tersebut akan mempengaruhi cepat atau lambatnya partikel-partikel mengendap dalam bak sedimentasi. Pada tahap ini akan dilihat tingkat efisiensi flokulasi dan waktu sedimentasi yang diperlukan sesuai dengan karakteristik air baku yang masuk dalam tahap sebelumnya.

Konsentrasi koagulan yang sesuai akan menghasilkan flok yang bagus dan pada akhirnya akan meningkatkan kualitas air yang diolah. Namun, konsentrasi koagulan yang optimal tidak dapat dihitung dengan menggunakan formula tertentu melainkan harus ditentukan dengan jar test. Tujuan dilakukannya jar test koagulan adalah untuk menentukan tipe koagulan, konsentrasi 
optimal koagulan, pH optimal, penambahan bahan kimia lain, optimasi waktu pengadukan cepat dan pengadukan lambat (Geng, 2005) Menurut Miltner (2006), jar test koagulan memberikan prediksi performa pengolahan air pada skala instalasi, kecuali dalam hal turbiditas. Karena faktor hidrodinamik, konsentrasi optimal koagulan yang didapatkan melalui jar test koagulan biasanya selalu lebih rendah dibandingkan dengan saat diaplikasikan pada skala instalasi. Dalam penelitian mereka, ditemukan bahwa turbiditas optimal yang didapatkan pada skala laboratorium dua kali lebih kecil dibandingkan dengan skala instalasi. Oleh karena itu, hasil yang didapatkan dalam skala laboratorium tidak dapat langsung diterapkan pada instalasi melainkan harus disesuaikan dengan kondisi di lapangan.

\section{Jenis Koagulan}

Dua jenis koagulan utama yang akan dikaji adalah alum $\left(\mathrm{Al}_{2}\left(\mathrm{SO}_{4}\right)_{3}\right)$ dan Poly Aluminium Chloride (PAC). Kedua jenis koagulan tersebut paling banyak dipakai dan mudah diperolah di pasaran. Variasi konsentrasi koagulan akan diaplikasikan (0-50 ppm) pada berbagai jenis air baku. Bahan bantu koagulan akan dipakai apabila tingkat efisiensi koagulasi terlalu rendah ( $<50 \%$ ). Proses koagulasi bisa terhambat jika tingkat kekeruhan terlalu rendah atau terlalu tinggi. Oleh karena itu perlu ditemukan batas optimal pemakaian koagulan pada kondisi kekeruhan air baku yang berbeda.

\section{Analisis Jar Tes}

Jar Tes adalah metoda yang digunakan untuk menentukan kondisi optimum dan proses pengolahan air. Metoda ini dapat dilakukan untuk menentukan $\mathrm{pH}$ optimum, variasi dosis koagulan, alternatif kecepatan pengadukan atau menguji jenis koagulan yang berbeda. Gambar 1 menunjukkan alat jar tes yang terdiri dari beberapa tongkat pengaduk dan motor yang dapat diatur kecepatannya (Mihelcic dan Auer, 1999).

Percobaan dilakukan dengan dua perlakuan utama yaitu : menggunakan bahan koagulan aluminium sulfat dan poly aluminium chloride (PAC). Tujuan perlakuan ini adalah mencari bahan koagulan yang lebih efisien untuk penjernihan air di sungai yang diteliti. Pada Tabel 1 dijelaskan perlakuan yang dikerjakan dengan alat jar tes secara lebih terperinci.

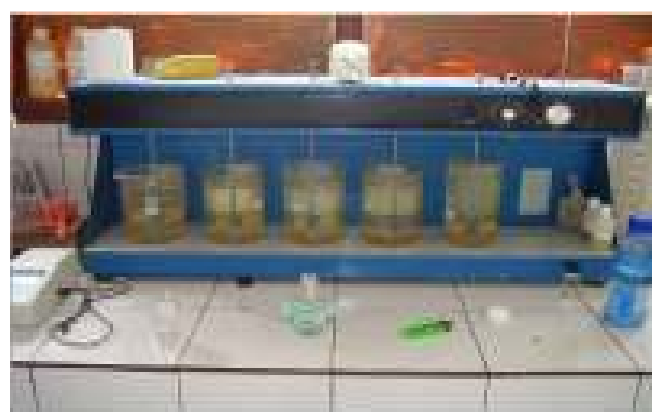

Gambar 1. Alat jar tes koagulasi

Tabel 1. Perlakuan pada prosedur jar tes

\begin{tabular}{ccc}
\hline Perlakuan & $\begin{array}{c}\text { Aluminium } \\
\text { Sulfat }\end{array}$ & $\begin{array}{c}\text { Poly } \\
\text { Aluminium } \\
\text { Cloride (PAC) }\end{array}$ \\
\hline Variasi & 10 & 5 \\
Dosis & 20 & 10 \\
(mg/liter) & 30 & 15 \\
& 40 & 20 \\
& 50 & 25 \\
\hline
\end{tabular}

\section{Hasil dan Pembahasan}

Waktu sedimentasi adalah waktu yang diperlukan agar flok yang telah terbentuk dapat mengendap. Diharapkan, setelah waktu sedimentasi sebagian besar flok mengendap. Pada Gambar 2-4 ditinjau hubungan antara kekeruhan air baku dengan waktu sedimentasi optimum. Dari Gambar 2 terlihat bahwa pada dosis alum 0, 10 dan 20 ppm, penurunan kekeruhan tampak tidak terlalu nyata. Sedangkan pada dosis alum 30, 40, dan $50 \mathrm{ppm}$, penurunan kekeruhan sangat nyata sampai pada menit ke lima.

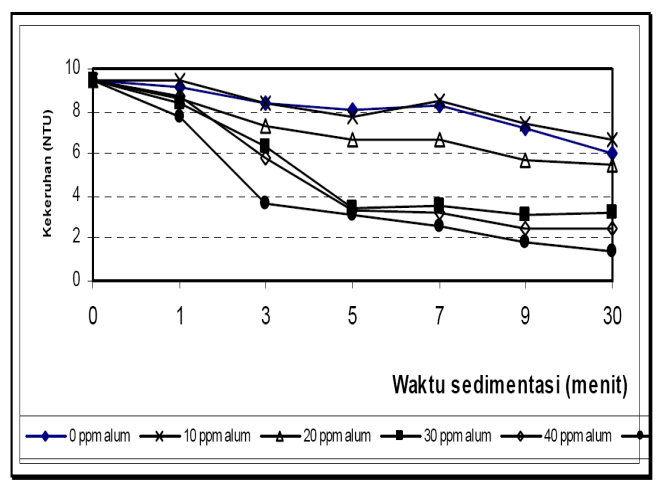

Gambar 2. Hubungan antara Waktu Sedimentasi dengan Kekeruhan pada Air Baku 9,4 NTU 


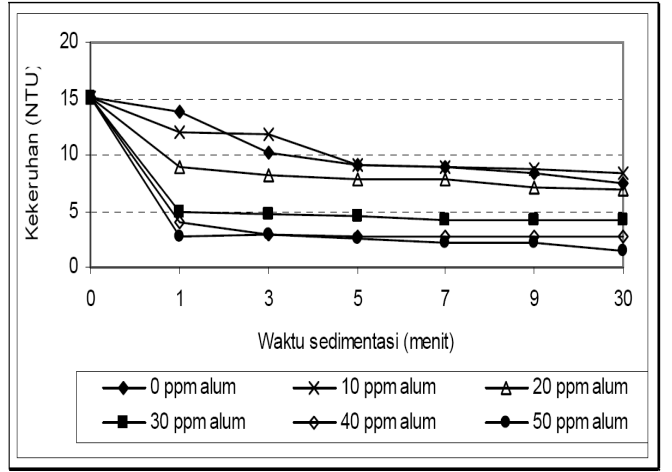

Gambar 3. Hubungan antara waktu sedimentasi dengan kekeruhan pada air baku 15,1 NTU

Pada kekeruhan air baku 15,1 NTU (Nephelometric Turbidity Unit) dengan dosis alum $10 \mathrm{ppm}$, terjadi penurunan kekeruhan sampai menit ke lima (Gambar 3). Tetapi pada dosis alum 20, 30, 40 dan $50 \mathrm{ppm}$ alum, penurunan kekeruhan telah nyata sejak menit pertama sedimentasi. Mulai menit pertama sampai menit ke lima, penurunan kekeruhan masih berlangsung tetapi tidak terlalu besar. Setelah itu, nilai kekeruhan cenderung tetap.

Berdasarkan Gambar 4, pada air baku yang kekeruhannya lebih tinggi (30 NTU), penurunan kekeruhan sangat nyata sejak menit pertama sedimentasi. Setelah itu penurunan kekeruhan tidak lagi terlalu besar.

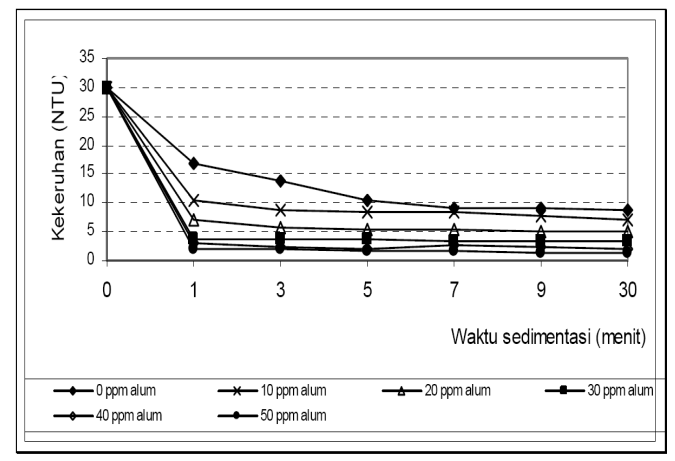

Gambar 4. Hubungan antan waktu sedimentasi dengan kekeruhan pada air baku 30 NTU

Dari hasil penelitian ini dapat disimpulkan kekeruhan air baku mempengaruhi waktu sedimentasi. Pada kekeruhan di bawah 15 NTU, waktu optimum sedimentasi adalah lima menit, tetapi pada air baku yang kekeruhannya di atas 15 NTU, waktu sedimentasi lebih cepat yaitu satu menit saja.
Hasil jar tes yang dilakukan terhadap air di sungai Krueng Raya dapat dilihat pada Tabel 2 dan 3. Dari kedua tabel dapat dilihat bahwa air sungai Krueng Raya dapat diolah dengan bahan koagulan aluminium sulfat pada dosis 20 ppm, sedangkan jika menggunakan bahan koagulan PAC memerlukan dosis optimal $15 \mathrm{ppm}$.

Berdasarkan PP 82 Tahun 2001 maka kedua lokasi pada Stasiun 1 (Sungai Krueng Raya) dan Stasiun 2 (Sungai Krueng Raya Muara) tidak layak sebagai air baku air minum. Namun hasil analisis jar tes menunjukkan bahwa air sungai di Stasiun 1 yang terletak sekitar $2 \mathrm{~km}$ dari muara, dapat diolah menjadi air bersih melalui proses koagulasi, flokulasi, sedimentasi, filtrasi dan disinfeksi. Berdasarkan data tersebut maka Sungai Krueng Raya pada stasiun 1 dapat digunakan sebagai sumber air baku air bersih dengan melalui proses pengolahan untuk dapat memenuhi kebutuhan di wilayah Kecamatan Masjid Raya, Kabupaten Aceh Besar.

Tabel 2. Hasil jar tes air Sungai Krueng Aceh dengan koagulan Aluminium Sulfat

\begin{tabular}{lccccc}
\hline \multirow{2}{*}{ Parameter } & \multicolumn{5}{c}{ Konsentrasi Aluminium Sulfat (ppm) } \\
& 0 & 20 & 25 & 30 & 35 \\
\hline $\mathrm{pH}$ & 7,92 & 7,35 & 7,22 & 7,16 & 7,15 \\
Turbiditas & 4,54 & 3,03 & 1,71 & 1,64 & 1,82 \\
\hline
\end{tabular}

Tabel 3. Hasil jar tes air Sungai Krueng Aceh dengan koagulan PAC

\begin{tabular}{lccccc}
\hline \multirow{2}{*}{ Parameter } & \multicolumn{5}{c}{ Konsentrasi PAC (ppm) } \\
\cline { 2 - 6 } & 0 & 15 & 20 & 25 & 30 \\
\hline pH & 7,92 & 7,5 & 7,5 & 7,45 & 7,3 \\
Turbiditas & 4,54 & 3,63 & 2,27 & 1,63 & 1,39 \\
\hline
\end{tabular}

\section{Kesimpulan}

Dari hasil penelitian mi dapat disimpulkan kekeruhan air baku mempengaruhi waktu sedimentasi. Pada kekeruhan dibawah 15 NTU, waktu optimum sedimentasi adalah lima menit, tetapi pada air Baku yang kekeruhannya diatas 15 NTU, waktu sedimentasi lebih cepat yaitu satu menit saja. Hasil jar tes yang dilakukan terhadap air di sungai Krueng Raya dapat dilihat bahwa air sungai Krueng Raya dapat diolah dengan bahan koagulan aluminium sulfat pada dosis $20 \mathrm{ppm}$, sedangkan jika menggunakan bahan koaguLan PAC memerlukan dosis optimal $15 \mathrm{ppm}$. 


\section{Daftar Pustaka}

American Society of Civil Engineering and American Water Works Association, Water Treatment Plant Design, $2^{\text {nd }}$ Ed., McGraw Hill, New York, 1996; p. 80-95.

Gebbie, P., Using Polyaluminium Coagulant in Water Treatment, Proceeding of the 64th Annual Water Industry Engineers and Operator's Conference, Bendigo-Australia, 5-6 September 2001, p.1-9, Bendigo, 2001.

Geng, Y., Applications of Flocs Analysis for Coagulation Optimization at the Split Lake Water Treatment Plant, Master Thesis, University of Manitoba, Manitoba, 2005, p. 9-14,18-28.
McGhee. T. J., Water Supply and Sewage, 6th Ed., McGraw Hill International Edition, Singapore, 1991.

Miltner, R. J., Coagulation, http://www.epa.gov/nrmrl/pubs/6001110/6 00r01110chap10.pdf. (Akses: 2 November 2006)

Mihelcic, J. R.; Auer, M. T., Fundamentals of Environmental Engineering, John Wiley \& Sons, Inc., New York, 1999; p. 7-10.

Singh, T. S.; Parikh, B.; Pant, K. K., Investigation on the sorption of aluminium in dringking water by low-cost adsorbents, Water SA, 2005, Vol. 32(1), 49-54. 